\title{
'Look What We Have Gone Through': Representation and Memory in the Bogside Murals in Northern Ireland
}

\author{
LAURA AGUIAR, Queen's University Belfast
}

\begin{abstract}
Murals have been painted on the outside walls of houses and businesses in Northern Ireland and have functioned as visual evidence of people's experiences of the conflict known as the Troubles. Created in 1994, The People's Gallery is a series of twelve murals painted by three local artists in the Bogside district in Derry. This article examines how the murals 'remember' the conflict, what stories are included or excluded, how 'Us' and 'Them' are portrayed, and how the depiction of the past relates to the present. The analysis shows that the murals focus on the Bogside's own experiences, portraying 'Us' as victims and as activists. The Other is represented directly by the image of the British army/RUC, and indirectly by the image of the chaos and violence caused to 'Us'. Due to the lack of sectarian messages, The People's Gallery can have a positive use as a storytelling tool in Northern Ireland's current transitional scenario.
\end{abstract}

\section{KEYWORDS}

Murals; Bogside; Derry; Memory; Othering; Representation; Troubles

\section{Introduction}

Voted as one of the Top Ten cities in the world to visit in 2013 by Lonely Planet (2012), and holding the title of UK City of Culture for the same year, Derry-Londonderry (Northern Ireland) has increasingly seen tourists flocking into its historic walls to enjoy a wealth of cultural events. With such optimist atmosphere, it may be hard for tourists to imagine the city's troubled past, which has been 'shaped by violent and traumatic conflict focused on spatial imposition and contestation of state power, remembered in highly politicised cultures of public commemoration' (Dawson 2007, 92).

The nationalist working-class community of the Bogside represents one of the main stages of civil rights marches, riots, brutal house searches, clashes with the British army and the Royal Ulster Constable (RUC), and also of infamous incidents, such as the Battle of the Bogside and Bloody Sunday. ${ }^{1}$ Along the district's main street, Rossville Street, a series of twelve murals can be seen on the façade of two and three-storey council buildings, reflecting back on

\footnotetext{
${ }^{1}$ The Battle of the Bogside took place in August 1969 after locals impeded the entrance of the RUC (Northern Irish Police) in the Bogside. After two days, eight people were killed, 750 injured, almost two hundred houses and buildings demolished and ninety required repairs. Bloody Sunday started with a peaceful civil rights march and culminated in bloodshed when British soldiers opened fire against the marchers. Fourteen were killed and hundreds were injured and, from then on, the civil rights movement ended and paramilitary activity escalated in Northern Ireland. For more details on both events see McKittrick and McVea (2002).
} 
events that took place during the Troubles. These murals were painted by The Bogside Artists, a group formed in 1993 by locals Tom Kelly, William Kelly and Kevin Hasson, and were named The People's Gallery. ${ }^{2}$

Murals have been painted on the outside walls of houses and businesses in Northern Ireland for more than a century and have become a popular practice of communication. They have articulated hopes and fears, and the political identity and ideology of people in nationalist and loyalist communities (Rolston 2012, 14). Most of the two thousand murals painted since the early 1900s are spread across Northern Ireland and were either left to fade or replaced by other murals with different messages.

They hold such importance that, even after the signing in 1998 of the Good Friday Agreement, which established the power-sharing government between nationalists and unionists and furthered the peace process, the question of 'what to do with the murals' has often been discussed. In one such discussion, Reverend Gary Mason, from East Belfast, asks: 'Now that there's peace, why should we have war on our walls? We've taken the gun out of politics; now we need to take it out of the murals' (cited in Rolston 2012, 7). Various grants have been given to cross-community projects, such as the Re-Imaging Communities Programme, ${ }^{3}$ to paint new murals or to replace militaristic imagery with positive messages.

This paper examines how the Bogside murals have formed the cultural memory of the Troubles. Cultural memory is the field of 'cultural negotiation through which different stories vie for a place in history' (Sturken 1997, i). It is where memories are produced, shaped and distributed through cultural means such as murals. Adopting a combination of Ethnographic methods with Critical Discourse Analysis, this study attempts to understand how the Bogside murals remember the conflict, what stories are included and which ones are excluded, how Bogsiders and Others are portrayed, and how the depiction of the past relates to the present. I begin with a brief contextualisation of the conflict and of the practice of mural painting in Northern Ireland. Then, I examine how the murals contribute to the cultural memory of the Troubles and finish with a discussion of the murals' potential in a society trying to move away from political violence.

\section{A Troubled Conflict}

Various paradigms have been used to interpret the conflict known as the 'Troubles' (for more nuanced readings, see McKittrick and McVea 2002, and Dawson 2007). The ethnic paradigm, which is often used by the media and governments, regards the Troubles as a conflict between 'two warring tribes': republicans/nationalists (mostly Catholics) against unionists/loyalists (mostly Protestants). However, Graham Dawson believes that the conflict involved more protagonists and can be characterised by 'systematic and sustained abuses of human rights by the British State, and a systematic blurring, by all protagonists of violence, of the categories of armed combatants and unarmed civilians' (Dawson 2007, 9). The duration of the Troubles is conventionally dated from the late 1960s, with the start of the Civil Rights Movement, until 1998, with the signing of the Good Friday Agreement.

\footnotetext{
${ }^{2}$ Together with the series of twelve murals, The People's Gallery also included a studio which functioned as a museum and workplace. The studio closed in 2011 due to lack of funding. Check the artists' website for more information on the Gallery: www.bogsideartists.com/

${ }^{3}$ For an analysis of various projects, including the Re-Imaging Communities Programme, see Rolston (2012).
} 
During the Troubles, over 3,500 people died and over 40,000 were injured (McKittrick and McVea 2002). These numbers may seem to be relatively low when compared to the 700 Palestinians killed during the two-year Intifada, or the 65,000 killed in one decade in El Salvador (McWilliams 1995, 13). However, the length of time over which the conflict has been sustained and Northern Ireland's small territory makes the Troubles distinctive. As Chris Ryder points out, 'if a similar level of violence had taken place in Britain over the same period, there would have been 100,000 dead, one million shooting incidents and some half a million bombings' (2000: xiii). The conflict has also left psychological scars in Northern Ireland, where 'one in five people has suffered multiple experiences relating to the Troubles' (Muldoon et al. 2005. 87-88).

Since the signing of the Good Friday Agreement in 1998, loyalist and republican paramilitary groups have completed the decommissioning of their weapons, unionists and nationalists have governed in a power-sharing system, and the economy has experienced periods of growth and recession. Many communities remain divided by walls and gates, and incidents such as murders ${ }^{4}$ and riots ${ }^{5}$ still occur. As Alistair Little, a former loyalist paramilitary currently working on peace building initiatives, rightly sums up: 'The outside world thinks we're now at peace, but there's lots of work still to be done. It's a fragile peace' (Little and Scott 2009, 207).

\section{Open-air Canvases}

Mural painting is everywhere: popular tales are depicted on the outside walls of cafes in Tanzania; a person who has visited Mecca can paint images of Islam on the outside walls of their houses in Egypt; and, in European countries such as England and Germany, there are murals on a wide range of themes, from unemployment to feminism (Rolston 1998, viii). In Northern Ireland, the first murals were painted in 1908, but it was only throughout the Troubles that their production flourished. The working-class districts of Belfast, such as Falls Road and Shankill Road, and the Bogside in Derry-Londonderry, are the places with the largest number of murals.

Murals consist of pictures painted on the walls of houses and commercial establishments and have been used to display people's experiences of the conflict, to pay tributes to victims and heroes, to protest against violence, and to demarcate boundaries. They are a medium to tell stories and are dependent on, and vulnerable to, weather conditions, acts of vandalism, and the community's approval or disapproval. According to Woods, these are

factors that can bring the already transitory existence of a painting to a premature end. Most murals will last roughly six months without care; beyond this they rely on the continued concern of the community and the artists for their upkeep (1995).

Rolston (2012) notes that murals were 'intimately implicated in the war, mobilising local support, reaffirming beleaguered ideologies and railing against the state and its forces, in the case of republican murals, and against nationalists and republicans, in the case of loyalist murals' (4). Throughout the Troubles, murals became not only a dynamic form of symbolic expression, but a crucial symbol of the conflict. This can be seen in the media's frequent use

\footnotetext{
${ }^{4}$ In 2012 prison officer David Black was shot dead on his way to work by a dissident republican group.

${ }^{5}$ On 3 December 2012, Belfast City Council voted to fly the union flag at City Hall only on designated days and, up to the time of writing, weekly protests have taken place, with some of them ending in violence.
} 
of murals to convey a sense of authenticity in films and dramas ostensibly set in Belfast, 'even when this requires the painting of a paramilitary mural in Dublin, Cardiff or Manchester' (Jarman and McCormick 2005, 50).

However, with the peace process in the 1990s, the content and purpose of the murals changed. Muralists located in nationalist districts removed most of the masked men and guns and adopted a more commemorative tone, as if trying to look 'back in order to look forward [and] these murals argued that twenty five years was enough' (Rolston 1998, vi). For them, there had been a range of themes for twenty years; this meant that removing the guns was less drastic as there were still other themes that could be represented (Rolston 2012, 6). Muralists in loyalist districts, on the other hand, found removing the guns more problematic and suffered with the lack of choice of alternative themes to depict (Rolston 2012,6). They then decided to focus on sport achievements, most notably by footballer George Best, and to pay tribute to the Ulster Volunteer Force (UVF) soldiers who formed the core of the British army, decimated in the Battle of the Somme ${ }^{6}$ during World War I.

While almost two thousand murals have been documented since 1970, today this open-air collection has been reduced to a few hundred, as many have been replaced or left to fade. This is because paintings remain and are sustained

as long as they have a purpose and a meaning to the people who live with them and value them. When their value, meaning and purpose has come to an end they are abandoned, ignored, defaced, destroyed, removed, replaced or redesigned (Jarman and McCormick 2005, 69).

However, this is not the case of the Bogside Murals. As I will discuss in the following pages, their content and purpose have enabled them to have a permanent character and become part of the landscape of the Bogside district.

\section{Memory and Murals}

The sense of public memory is evident in human civilisation as far back as the construction of pyramids in Egypt or the eulogies in ancient Greece. However, it was only in the nineteenth century that memory became a subject of scientific research in several fields, mainly in sociology and psychology. The studies of memory in social sciences only flourished in the 1980s thanks to a 'commemorative fever' (Misztal 2003, 2), when conflicts were constantly re-narrativised and commemorated and public discourse on the past was on the rise.

Memory is a narrative responsible for defining a culture and giving it identity. Evidence of the past can be noticed in various modes of public expression in everyday life, from clothing to art exhibitions, and from public memorials to television productions. The media certainly form one of the main mnemonic sites in contemporary society. Through memory 'internal selves have connected with external environments, pasts with presents, random experiences with unconscious routines' (Zelizer 1995, 214). Its analysis thus may reveal how a certain culture functions, how it deals with politics, as well as how cultural arenas such as art, popular culture, and activism intersect.

\footnotetext{
${ }^{6}$ The Battle of the Somme is considered one of the largest war battles and one of the bloodiest military operations ever recorded.
} 
Since the 1980s, memory studies have offered different theoretical and methodological approaches and various alternative definitions of the object of study, ranging from social and collective memory to popular and cultural memory. I focus on the latter concept because my aim is to examine one of the cultural vehicles that constitute memory: the murals. Borrowing the definition from Anthropology, culture refers to a 'whole way of life, a broad range of activities which are geared towards classifying and communicating symbolically within a society' (Sturken and Cartwright 2009, 3). Cultural memory refers to

the representation by a social group of processes, events or experiences that have taken place or are believed to have taken place in its past and that articulates its sense of a lived connection between past and present, and the meanings it makes of that connection (Dawson 2007, 12).

Cultural memory opens up the event that is remembered and turns it into a 'multi-sided jigsaw puzzle that links events, issues or personalities differently for different groups' (Zelizer 1998, 3). Images work as vehicles of memory and their potential lies in freezing the representation of the past at a powerful moment already familiar to individuals. Images also work in patterned ways, 'concretising and externalising events in an accessible and visible fashion that allows us to recognize the tangible proof they offer of the evens being represented' (Zelizer 2004, 160). When a medium such as wall painting becomes a text, it must be read and then interpreted, since meanings are continuously constructed and maintained. Thus, our efforts to understand the relationship between social actors, structures of power, and their connections with the street must take into account how meanings are changed, challenged, reinforced, and negotiated through a process of interpretation (David 2007, 234).

In the island of Ireland, as Ian McBride points out, the interpretation of the past has always been at the heart of national conflict and, perhaps more than in other cultures, collective groups have expressed their values and assumptions through their representations of the past (cited in Dawson 2007, 7). Like in other conflicts such as Rwanda and South Africa, the past in Northern Ireland continues to torment in the present because it is not past; the country is in the midst of a peace process in which wounds are on a continuing healing process. Therefore, examining the images depicted in the murals enables an understanding of how people make sense of the world since images 'can be used to construct stories that become the building blocks of an argument' (Stanczak 2007, 11).

\section{Visiting the Bogside}

If the construction of memory is a social and cultural process, then it is also relevant to examine the role of the institutions responsible for this construction as well as the objects, places and practices that embody cultural memory. Jarman reminds us that

a building or street without a mural is as anonymous as any other, just another version of the red brick or grey concrete walls that dominate working-class residential areas throughout Britain and Ireland. However, the appearance of a mural situates a house and its locality within a universe of political conflict, sectarian divisions and paramilitary groups (1998). 
To this end, I combine Ethnographic methods with Critical Discourse Analysis to understand the interactions between muralists, the Bogside district and the images depicted in the murals. I visited the Bogside in May 2011 to carry out participant observation and semi-structured interviews with one of the Bogside Artists, Kevin Hassard, and with locals and tourists. Broadly speaking, ethnography refers to the description of a culture, its social realities and its making, and rather than studying people, it means learning from people (Spradley 1979, 3). It is an approach to experiencing, interpreting and representing knowledge (about society, culture and individuals) based on the ethnographer's own experiences (Pink 2007, 22). Therefore, using ethnography enabled me to participate in the everyday life of The People's Gallery, to watch what happens, to listen to what is said, to ask questions and also to see how things are shown as well as which ones are not shown. Norman Fairclough's Critical Discourse Analysis was particularly useful to examine the content of each mural and identify discourses of memory. The approach enabled me to understand the wider social fields and processes within which these discourses are embedded (Fairclough 1998, 161).

\section{Results from the Field}

The combination of Ethnography and Critical Discourse Analysis was fruitful to answer questions regarding the content of the murals and their wider context. My aim is to investigate how the murals 'remember' and depict events of the Troubles and not whether their representation is a true version of facts. As Sturken explains,

memory is a narrative rather than a replica of an experience that can be retrieved and relived [...] what we remember is highly selective, and how we retrieve it says as much about desire and denial as it does about remembrance $(1997,7)$.

\section{Three muralists, Twelve Canvases and One Street}

Friends since childhood, and working together since 1993, the group The Bogside Artists is formed by Tom Kelly, William Kelly and Kevin Hasson. After unveiling their first mural, The Petrol Bomber, in 1994, the three artists reflected on the symmetrically similar gable-end walls on Rossville Street and decided they would paint a series of murals that would reflect what Bogsiders endured during the Troubles. They named their work The People's Gallery.

They chose the murals as the medium to tell stories because of their permanent and public character. As Hasson argues,

if something comes on the TV, you watch it and in the next day you will have forgotten maybe half of it [...] so the murals are there permanently and we have used them in such a public way and as a main vehicle and our story will be constantly on the public domain and not just as a flash on the TV (2011).

The twelve murals of The People's Gallery are not organised into a chronological narrative of the events, but each mural has a sign with a brief contextualisation and has been illuminated and repainted recently thanks to people's donations. The process of mural production starts with the brainstorming of the theme. The images are based on existing photographs or footage and the artists do a montage of different images, with one single figure as a main focal point. Producing a single mural generally requires two to three weeks to complete and 
costs between $£ 600$ to $£ 1,000$ for the paints, scaffolding, and ladders. The production is financed by the people of Derry from both communities, but mostly from nationalists.

\section{From Greyness to Colour}

The first murals painted in the early 1990s have dark tones, which could be read as a reflection of the pessimism and the mourning sentiments experienced by the Bogside during that time. Even though a secret channel of communication between the British government and republican paramilitary groups had been established, the occurrence of violent incidents continued in Northern Ireland and increasingly in England. Not even the 1994-1996 IRA ceasefires brought hopes of reaching peace. Although it came as a 'huge step, undertaken unilaterally, and no one was sure what would happen next' (McVea and McKittrick 2002, 199), the ceasefire statement was received 'with suspicion rather than celebration. Unionist politicians warned that it was a delusion and a trick rather than a genuine move, though most nationalists and republicans instinctively believed the conflict had drawn to an end' (McVea and McKittrick 2002, 200).

Throughout the 1990s, the artists used red tones to highlight the bloody nature of the conflict: in the streets killing innocent children, in the prison cells in Long Kesh and Armagh Gaol, and in violent repressions of civil marches. The scenario depicted in these murals is of destruction: debris, destroyed homes, and loose windows. The smoke, frequent in most murals, complements this chaotic scenario together with people rioting in the streets, tanks entering the district and soldiers breaking brutally into houses. After the Good-Friday Agreement, especially in early 2000s, new discourses entered The People's Gallery. The bloodshed, violence and destruction gave way to peace and hope, and in the memory of the Bogside, there were weapon decommissions, hope for peace and also tributes to the efforts of infamous peacemakers. One of the murals is the result of a cross-community workshop carried out by the artists with youth groups in Derry. The optimism depicted in the murals could be read as a reflection of what was happening within the nationalist community at that time, which overwhelmingly supported the Agreement and viewed it 'as a historic departure based on the principle of inclusion' (McVea and McKittrick 2002, 239). The Agreement also brought a sense of a new era in which nothing would ever be the same again (222).

This shift from a dark and bloody period to one of hope shows that the remembrance of past events is closely linked to the present context. Memory 'is, by definition, a term which directs our attention not to the past but to the past-present relation. It is because "the past" has this living active existence in the present that it matters so much politically' (Popular Memory Group 2006, 46). The artists' pessimism in the early 1990s are reflected in the grey depiction of events that took place almost thirty years earlier, such as the Battle of the Bogside and Bloody Sunday. After the signing of the Good Friday Agreement, the shift from a pessimistic to an optimistic mood is depicted more colourfully in the images of broken guns and peace figures, such as the dove and the peacemakers.

Us

The murals deliberately focus on 'Us', which can refer to both Bogsiders, including the artists, and Rossville Street, where key events took place during the Troubles. The muralists' intention was to show 'how all those events impacted on the ordinary people, people that 
didn't have a political bone in their body, parents that were trying to raise their children on very difficult circumstances' (Hasson 2011).

'Us' in the murals are mostly young individuals, male and female. Indeed, the role of the youth in the conflict was one of the most constant themes in The People's Gallery. Whether as a victim, as a protester, or as a martyr, at least seven murals give prominence to youngsters. Some murals place the image of youth in the centre to draw attention to the fact that youngsters paid the price of the war with their own lives. They remind us that innocent children are often caught in the crossfire. However, the youth of the Bogside are not only depicted as victims of the conflict, but also as strong believers in their struggle, as activists marching for civil rights, standing defiantly against a tank, throwing petrol bombs at the army, or making 'noise' with bin lids or loudhailers.

Ed Cairns and Tara Cairns studied the youth involvement in the conflict and concluded that children in Northern Ireland have had direct and indirect experiences of the political violence. They cite an early 1970s survey which revealed that over half of the interviewees reported some degree of harassment on their way to post-primary school (Cairns and Cairns 1995, 97). Another survey from 1985, based on ten and eleven-year-old children, revealed that "almost 20 per cent of the children reported that they had been in or near a bomb explosion and 20.1 per cent reported that they had a relative or friend injured or killed because of the Troubles" (Cairns and Cairns 1995, 97). It comes as no surprise, thus, to see that the youth's experiences during the Troubles have been given prominence in the murals.

The murals also remind us of the active role of women during the conflict. Indeed, some murals highlight female activists during the civil rights marches in late 1960s, with the former mural focusing on Bernadette 'Devlin' McAliskey ${ }^{7}$, one of the best known activists from Northern Ireland. According to Sales (1997), women have been at the 'forefront of community organisations which have attempted to unite both communities around issues of common concern' and have also been 'prominent in peace movements, but some women have also become involved in paramilitary activity in both loyalist and Republican organisations, and in the political parties associated with them' (Sales 1997, 1). ${ }^{8}$ Women are also depicted as peacemakers, such Mother Theresa, Nelson Mandela, Martin Luther King and John Hume. The People's Gallery also remembers women as innocent victims of the Troubles, such as 14-year-old Annette McGavigan, who was shot dead by a British soldier while gathering coloured stones for a school art project in 1971.

Like most conflicts, the Troubles have also produced 'martyrs and heroes' for its communities. The martyrdom of the republican prisoners who endured the hardship of the hunger strikes and the 'Blanket and No Wash' protests, in which prisoners refused to wear uniforms and were, in turn, denied the use of toilets, have been embedded in the republicans' popular culture. As McKittrick and McVea note,

there could have been no more definitive display of political motivation than the spectacle of ten men giving their lives in an awesome display of self-sacrifice and determination [...] The hunger strikers thus won political status in the eyes of the world $(2002,147)$.

\footnotetext{
${ }^{7}$ To read more on McAliskey's story, see her autobiography The Price of My Soul (1969) and Lelia Doolan's film Bernadette: Notes on a Political Journey (2011).

${ }^{8}$ To read more on women's roles in the Troubles, see Aretxaga (1997), Ward (2006) and Alison (2009).
} 
Equally, the fourteen civilians killed during Bloody Sunday have also been publicly and ritually remembered on a regular basis. The People's Gallery may function as a space where such myths circulate. Its murals act 'as reminders of the bitter stages of a society's evolution', and they come to be regarded as a site of the Bogside's 'transcendence over the conditions of unjust treatment in times of war or of resistance to cruel and oppressive political regimes' (Logan and Reeves 2009, 5).

If the preservation of recollections can rest on their anchorage in space (Nathan Watchel, cited in Zelizer 1995, 224), then it can be said that 'Us' in the cultural memory of the Bogside murals is also represented in Rossville Street. Some places can be more 'closely associated with public memory than others, for example, museums, preservation sites, battlefields, memorials and so forth' (Dickinson et al. 2010, 24). This way, the placement of The People's Gallery on Rossville Street enable the murals to act as a reminder of the bitter stages of the Troubles and of people's potential to act inhumanely with one another. It is also a reminder of the Bogsiders' struggle against injustice and oppression.

One of the murals represents a case of imprisonment. Even though it did not take place in this street, it still serves to highlight how imprisonment has influenced the people of the Bogside. Shirlow and Dowler (2010) estimate that the number of people affected directly by political imprisonment could be over one hundred thousand (Shirlow and Dowler 2010, 384). In 1971 alone, when internment without trial was adopted, 'over $1 \%$ of the Catholic male adult population in Northern Ireland had been imprisoned or interned and over $2 \%$ had been arrested and interrogated' (Murray 1998, 9). The Bogside was not different and saw many of its inhabitants arrested.

Although the murals focus on the nationalist Bogside as 'Us', the artists have opted to leave out expressions of Catholicism and Irishness, such as the Irish tricolour flag, shamrocks, harps or gaelic writings which are commonly depicted in similar murals elsewhere. As Hasson (2011) points out, 'the kids standing in front of the British vehicle, behind the big grid with the stone in his hand: Tianmon Square, Gaza, anywhere. They are all the same; children murdered and killed everywhere in conflict'. The artists believe that the increasing number of tourists in Derry and the expansion of photographs of the murals on the internet have enabled 'Us' to be more easily related to by those from other conflict zones.

The lack of Irishness combined with techniques to convey realism, such as the use of grey tones, accentuation of features and use of known photographs (such as the depiction of Raymond McCartney on a hospital bed on the fifty-third day of his hunger strike) add a historic value and authenticity to the stories depicted. This, in turn, enables the murals to become a document of the Troubles' cultural memory and history, and explains why they have often been reproduced in films, postcards, and history books.

\section{Others}

The Other is represented directly and indirectly by British soldiers and the RUC as perpetrators. Directly, they are depicted brutally hammering doors for house searches or holding guns and stepping on a bloody banner during the civil rights marches. Indirectly, the perpetrators are portrayed by images showing the consequences of what they have done to Bogsiders. They are represented by the use of CS gas and armoured tanks in some murals, and also in the depiction of the hunger strikers' suffering. Some murals depict victims killed 
by perpetrators: Anette McGavigan, shot dead by a British soldier; Brian Coyle, killed by a bomb that he tried to throw over a wall to hit an army patrol; and Manus Deery, who was shot dead by a soldier in 1972. Charles Love, who was killed by flying debris from an IRA bomb explosion in 1990, is also depicted. Love's image represents the memory of the paramilitaries' role as perpetrators during the conflict.

When referring to filmic images, Margaret Bergquist believes that these representations are 'reflective of the thoughts, ideologies and prejudices of the society in which they are created' (Bergquist 1996, 18). This is also applicable to murals and I concur when she argues that images can also contribute to the formation of these thoughts, ideologies and prejudices. Thus, by depicting the Army and the RUC as the main perpetrators, the Bogside murals are not only reflecting the Bogsiders' feelings towards security forces, but they are also contributing to the creation of a negative memory of these forces for future generations of Bogsiders and visitors of The People's Gallery.

\section{Personal Memories}

It can be noted that the memory of the Troubles depicted in the murals blends with the personal memory of the muralists. As Sturken (1997) remarks, 'in acts of public commemoration, the shifting discourses of history, personal memory, and cultural memory converge' (44). Moreover, this convergence shows not only how people interpret their past at a personal level, but it also offers a tool to understand how historical events have developed. The muralists have included personal stories in each mural: Anette McGavigan was a cousin of Hasson, and Manus Deery was a cousin of the other two muralists, William and Tom Kelly. The three muralists were also at the march that led to Bloody Sunday. Hasson, who had seen his family being brutalised by the RUC, was a protester and had thrown stones at the RUC when he was younger.

\section{Conclusions}

This paper has examined how the Bogside murals represent the cultural memory of the Troubles. The Troubles was a conflict in which female and male youngsters were both victims and agents of change. They are depicted marching, rioting, throwing stones, but also running to save their lives. The British army, the RUC and, to a certain extent, paramilitary groups are depicted as perpetrators. They are represented brutally searching houses, repressing marches and killing innocent children. According to The People's Gallery, the conflict was a dark period marked by riots, brutal house searches and destruction, but it was also a period of unity, when a whole community fought for their rights, and when hopes were restored with the 1998 Good-Friday Agreement.

The findings reveal that the murals articulate a partial and selective narrative focused on what the Others have done to Us, what we have suffered and how our people have fought back (Dawson 2007, 3). This is because, while focusing on 'our' story in the conflict, politicised communal memories 'tend to withhold recognition, to forget, and to deny the traumas of the Other: recognition of the trauma is felt to imply recognition of the political narrative that articulates its significance' (Dawson 2004, 191). The representation of 'Us' and the Other are reflective of the society within which they are created. 
Victims, martyrs, and villains are not only part of the Bogsiders' memory of the Troubles, but of the very personal memory of the artists. Acknowledging that cultural memory and personal memory can complement each other enables a 'better understanding of both the personal trauma, as it is viewed within a social context, and of the social milieu, as reflected in the individual's life' (Benezer 2004, 30).

However, some absences can also be noted in my analysis, such as more reference to loyalist communities and paramilitary groups. Even though there is an indirect reference to the IRA as perpetrators, my analysis could not offer a more nuanced reading on the artists' and Bogsiders' views of paramilitary groups and their activities. Their invisibility on the murals may suggest that memories are kept only of those events, people and places which are deemed "worthy of preservation, based on some kind of emotional detachment" (Dickinson et al. 2010, 7).

While carrying out this research on the Bogside, the commitment that muralists and Bogsiders profess towards each other became obvious. Bogsiders have been the murals' main sponsors and they have never caused any damage to them. This supportive nature within the Bogside is indeed a feature of many nationalist communities in Northern Ireland. As Dawson (2007) explains, 'these communities' creative, mutually supportive and independent traditions of self-help and community activism from below were born out of the history of the Catholic ghetto and its culture of resistance against the Unionist and the British state machines' (153).

Why is it important to study how memories, such as the ones conveyed in these murals, are produced and distributed? First, the analysis of a medium of storytelling like these murals reveals how violent events which dramatically altered people's lives are re-lived, re-worked, made sense of, come to terms with, and integrated (Judith Zur, cited in Rogers et al. 2004, 51). Secondly, analysing representations of memory can be useful to understand how people interpret their past at a personal and at a collective level, which 'is an invaluable contribution to other documentary evidence and provides a rich texture to our understanding of historical developments' (Dickinson et al. 2010, 20). Thirdly, examining how Bogsiders' memories are represented in cultural forms, how an image of one Bogsider is taken as representative of the entire district, and how the district is spoken for and on behalf of, enables an understanding of how Bogsiders see themselves and others like themselves, and how they see their place in Derry (Dyer, cited in Bergquist 1996, 18).

So, how can the murals' depiction of the past influence the present or even the future? Scholars and practitioners in Northern Ireland agree that understanding the Other is a crucial tool for the current peace process (Dawson 2007; McLaughlin 2010). McLaughlin, for example, notes that

in the process of a society emerging out of a divided and violent past, different versions of that past need to be heard. One cause of the Troubles' violence was the silencing - political, social and economic - of the voices of a minority of the population $(2010,149)$.

I argue that murals that do not carry sectarian messages and focus on the human side of the conflict, as the Bogside murals do, could be used as an important tool for 'listening' to different versions of the past. The People's Gallery could be developed into a formal and 
informal memorial to offer a positive learning experience and educational resource for next generations.

However, in an 'island where the inhabitants defined themselves not by what they shared in common, but by what set them apart' (Little and Scott 2009, 26), the Gallery's overtly focus on 'Us' may not encourage the Other to use the murals as a tool to understand a different version of the past, and may end up confining the Bogside's story to nationalist communities and tourists. A further step to this research would be to compare responses from different communities, including Bogsiders, loyalists and foreigners. This would enable an important understanding of the murals' strengths and limitations in contemporary Northern Ireland.

\section{References}

Alison, M.H. (2009) Women and political violence: female combatants in ethnonational conflict, London: Routledge.

Aretxaga, B. (1997) Shatering Silence: Women, Nationalism and Political Subjectivity in Northern Ireland, New Jersey: Princeton University Press.

Benezer, G. (2004) 'Trauma Signals in Life Stories', in K.L. Rogers, S. Leydesdorff and G. Dawson (eds.) Trauma: Life Stories of Survivors, New Brunswick: Transaction Publishers.

Bergquist, M.I. (1996) Mother Ireland and the Gun: Representations of Women and Violence in the Films of Northern Ireland, Unpublished Masters Dissertation, Queen's University Belfast.

Cairns, E. and Cairns, T. (1995) 'Children and Conflict: A Psychological Perspective', in S. Dunn (ed.) Facets of the conflict in Northern Ireland, London: Macmillan.

David, E. A. (2007) 'Signs of Resistance: Marking Public Space Through a Renowned Cultural Activism', in G.C. Stanczak (ed.) Visual Research Methods: Image, Society and Representation, London: Sage.

Dawson, G. (2004) 'Trauma, Memory, Politics: The Irish Troubles', in K.L. Rogers, S. Leydesdorff and G. Dawson (eds.) Trauma: Life Stories of Survivors, New Brunswick: Transaction Publishers.

Dawson, G. (2007) Making Peace With the Past? Memory, Trauma and the Irish Troubles, Manchester: Manchester University Press.

Dickinson, G., Ott, B.L. and Blair, C. (eds.) (2010) Places of Public Memory: The Rhetoric of Museums and Memorials, Tuscaloosa: University of Alabama.

Fairclough, N. (1998) 'Political Discourse in the Media: An Analytical Framework', in A. Bell and P. Garrett (eds.) Approaches to Media Discourse, Oxford: Blackwell.

Hasson, K. (2011) Interview Transcript, 9 March, Unpublished Masters Dissertation, Stockholm University. 
Jarman, N. (1998) 'Painting Landscapes: the place of murals in the symbolic construction of urban space'. Available from: http://cain.ulst.ac.uk/bibdbs/murals/jarman.htm\#chap5 [accessed 01/02/2011].

Jarman, N. and McCormick, J. (2005) 'Death of a Mural', Journal of Material Culture, 10, 1, 49-71.

Little, A. and Scott, R. (2009) Give a Boy a Gun, London: Darton Longman Todd.

Logan, W. and Reeves, K. (2009) Places of Pain and Shame: Dealing with Difficult Heritage, New York: Routledge.

Lonely Planet (2012) 'Best in Travel 2013 - Top 10 cities'. Lonely Planet, 23 October. Available from www.lonelyplanet.com/themes/best-in-travel/top-10-cities [accessed 2.7.2014].

McAliskey, B. (1969) The Price of My Soul, London: Macmillan.

McKittrick, D. and McVea, D. (2002) Making sense of the Troubles: The story of the Conflict in Northern Ireland, Chicago: New Amsterdam Books.

McLaughlin, C. (2010) Recording Memories from Political Conflict: A Film-makers Journey, Bristol: Intellect.

McWilliams, M. (1995) 'Struggling for Peace and Justice: Reflections on Women's Activism in Northern Ireland', Journal of Women's History, 6, 4/7, 1 (Winter/Spring).

Misztal, B. (2003) Theories of Social Remembering, Philadelphia: Open University Press.

Muldoon, O., Schmid, K., Downes, C., Kremer, J. and Trew, K. (2005) The Legacy of the Troubles: Experience of the Troubles, Mental Health and Social Attitudes. Available at: http://www.legacyofthetroubles.qub.ac.uk/LegacyOfTheTroublesFinalReport.pdf [accessed 01/02/2011].

Murray, R. (1998) Hard Time: Armagh Gaol 1971-1986, Dublin: Mercier Press.

Pink, S. (2007) Doing Visual Ethnography Images, Media and Representation in Research, London: Sage.

Popular Memory Group (2006) 'Popular Memory Group: Theory, Politics, Method', in R. Perks and A. Thomson (eds.) The Oral History Reader. London: Routledge.

Rogers, K.L., Leydesdorff, S. and Dawson, G. (eds.) (2004) Trauma: Life Stories of Survivors, New Brunswick: Transaction Publishers. 
Rolston, B. (1998) Drawing Support 2: Murals of War and Peace, Belfast: Beyond the Pale Publications.

Rolston, B. (2012) 'Re-Imaging: Mural Painting and the State in Northern Ireland', International Journal of Cultural Studies, 15, 5447-5466.

Ryder, C. (2000) Inside The Maze: The Untold Story of the Northern Ireland Prison Service, London: Methuen.

Sales, R. (1997) Women Divided: Gender, Religion and Politics in Northern Ireland, London: Routledge.

Shirlow, P. and Dowler L. (2010) "Wee women no more": female partners of republican political prisoners in Belfast', Environment and Planning, 42, 2, 384-399.

Spradley, J.P. (1979) The Ethnographic Interview, United States: Wadsworth Group/Thomas Learning.

Stanczak, G.C. (2007) Visual Research Methods: Image, Society and Representation, London: Sage.

Sturken, M. (1997) Tangled Memories: The Vietnam War, The AIDS Epidemic, and the Politics of Remembering, Oakland: University of California Press.

Sturken, M. and Cartwright, L. (2009) Practices of Looking: An introduction to Visual Culture, New York: Oxford University Press.

Ward, R. (2006) Women Unionism and Loyalism in Northern Ireland: From 'TeaMakers' to Political Actors, Dublin: Irish Academy Press.

Woods, O. (1995) 'Seeing is Believing? Murals in Derry'. Conflict Archive on the Internet (CAIN). Available from: http://cain.ulst.ac.uk/bibdbs/murals/woods.htm [20/02/2011].

Zelizer, B. (1995) 'Reading the Past Against the Grain. The Shape of Memory Studies', Critical Studies in Mass Communication, 12, 2, 214-219.

Zelizer, B. (1998) Remembering to Forget: Holocaust Memory Through the Camera's Eye, Chicago: University of Chicago Press.

Zelizer, B. (2004) 'The Voice of the Visual in Public Memory', in K.R. Phillips (ed.) Framing Public Memory, Alabama: University of Alabama Press.

\section{Biography}

Laura Aguiar is a $\mathrm{PhD}$ candidate at Queen's University Belfast. Her practice-based research focuses on giving visibility to women's experiences of war and prisons through collaborative filmmaking. She co-directed and edited the 60min film We Were There, in collaboration with 
the Prisons Memory Archive and its participants. Laura has also worked as a freelance journalist in Brazil and Sweden. She can be contacted at laguiar01@qub.ac.uk. 